岡山地方における性病の疫学的研究

$$
\text { 第 } 3 \text { 報。 }
$$

岡山大学医学部皮隔科泌尿器科教室過去 8 ケ年（昭和 24 年

〜31 年) における性病の消長につにて

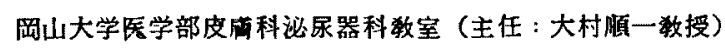

山村 英 太 郎

為 政 邦 輔

[昭和 32 年 10 月 23 日受稿]

我教室飞打いては，先に藤原氏等が昭和13 年〜23年仾る11ケ年の性病の消長飞ついて 報告しているが，この度はその引続きとして， 昭和24年一 31年に互る8 ケ年間に教室にて取 扱える性病患者につき種々なる臨床的角度よ り統計的て観察したので性病の現状を把握す る一助としたい。

\section{梳計的锶 察}

1）各年統計綱目として，性別，年令，配 偶関係，職業別，治療経過と分け，病型とし て性病を梅毒，淋疾，軟性下底，混合下措， 第四性病，更に梅毒については㩆症（第 I， II， III期），潜伏 (第II， III期，期不明），第
IV 期，先天性とし，淋疾については急性，覀 急性，慢性とし，之を更に合併症の有無によ り細分した，之等は第 1 表より第 8 表汇記载 した（第 1 表 $８$ 表迄参考）.

又各年度に括ける外来患者総数，皮暍科患 者緿数, 泌永器科患者総数, 性病患者総数を しらへ，性病患者総数の外来患者総数飞対す る\%，梅毒，軟性下底，混合下唐各総数の皮 屈科患者総数汉対する\%，及び性病患者総数 飞対する\%，更に淋疾患者棇数の泌尿器科患 者総数に対する\%，及び性病患者総数に対す る96を観察した。等は第 9 表に記載した (第 9 表参考).

第 1 表 昭 和 $24 \quad 4$ 年

\begin{tabular}{|c|c|c|c|c|c|c|c|c|c|c|c|c|c|c|c|c|c|c|c|c|c|c|c|c|c|}
\hline \multirow{2}{*}{ F } & \multirow[b]{2}{*}{ 型 } & \multirow{2}{*}{ 統計䌒目 } & \multirow{2}{*}{\multicolumn{2}{|c|}{$\begin{array}{l}\text { 性 別 } \\
\text { 男 女 }\end{array}$}} & \multicolumn{4}{|c|}{ 年 } & \multicolumn{3}{|c|}{ 令 } & \multicolumn{2}{|c|}{ 配 䬑 } & \multicolumn{4}{|c|}{ 㵝 } & \multicolumn{5}{|c|}{ 業 } & \multicolumn{3}{|c|}{ 治燎経過 } \\
\hline & & & & & $\sum_{10}^{1}$ & $\begin{array}{c}11 \\
2 \\
20\end{array}$ & $\begin{array}{c}21 \\
? \\
30\end{array}$ & $\begin{array}{c}31 \\
? \\
40\end{array}$ & $\begin{array}{c}41 \\
50\end{array}$ & $\begin{array}{c}51 \\
2 \\
60\end{array}$ & $\begin{array}{c}61 \\
7 \\
70\end{array}$ & 有 & 熘 & 壁 & 閔 & 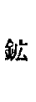 & 工 & 水 & 交 & 公 & 豩 & 然 & 全 & 半 & $\begin{array}{l}\text { 来 } \\
\text { 治 } \\
\text { 不 } \\
\text { 明 }\end{array}$ \\
\hline \multirow{6}{*}{ 梅 } & 暊 & 第 I 期11 & 11 & 0 & 0 & 2 & 6 & 2 & 0 & 0 & 1 & 3 & 8 & 2 & 2 & 0 & 0 & 1 & 1 & 2 & 0 & 3. & 5 & 4 & 2 \\
\hline & 性 & 第II 期 8 & 4 & 4 & 1 & 0 & 3 & 1 & 2 & 1 & 0 & 5 & 3 & 2 & 1 & 0 & 0 & 0 & 0 & 0 & 0 & 5 & 0 & 6 & 2 \\
\hline & 21 & 第III 期 2 & 2 & 0 & 0 & 0 & 1 & 0 & 1 & 0 & 0 & 2 & 0 & 1 & 0 & 0 & 1 & 0 & 0 & 0 & 0 & 0 & 이 & 2 & 0 \\
\hline & 潜 & 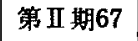 & 40 & 27 & 0 & 6 & 49 & 8 & 3 & 1 & 0 & 25 & 42 & 19 & 8 & 0 & 9 & 1 & 2 & 10 & 0 & 18 & 5 & 33 & 29 \\
\hline & 伏 & 第 III 期 20 & 13 & 7 & 0 & 0 & 5 & 8 & 4 & 2 & 1 & 18 & 2 & 4 & 7 & 0 & 1 & 0 & 1 & 4 & 0 & 3 & 2 & 12 & 6 \\
\hline & 90 & 期不明 3 & 0 & 3 & 0 & 0 & 1 & 0 & 2 & 0 & 0 & 2 & 1 & 0 & 0 & 0 & 0 & 0 & 0 & 0 & 0 & 3 & 0 & 3 & 0 \\
\hline \multirow[t]{3}{*}{ 毒 } & 第 & IV 期 2 & 2 & 0 & 0 & 0 & 0 & 0 & 0 & 0 & 2 & 2 & 0 & 0 & 1 & 0 & 0 & 0 & 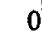 & 0 & 0 & 1 & 0 & 2 & 0 \\
\hline & 先 & 天 性 2 & 0 & 2 & 0 & 0 & 1 & 1 & 0 & 0 & 0 & 1 & 1 & 0 & 0 & 0 & 0 & 0 & 0 & 1 & 0 & 1 & 0 & 0 & 2 \\
\hline & & 愺 115 & 72 & 43 & 1 & 8 & 66 & 20 & 12 & 4 & 4 & 58 & 57 & 28 & 19 & 0 & 11 & 2 & & 17 & 0 & 34 & 12 & & 41 \\
\hline
\end{tabular}




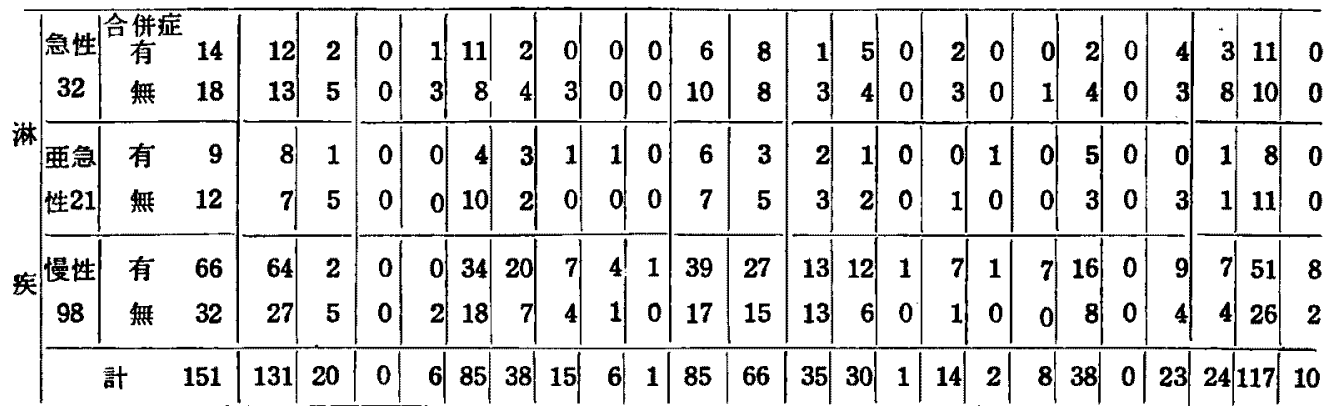

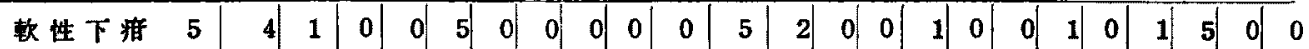

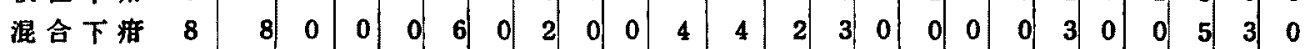

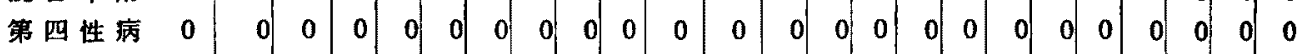

\begin{tabular}{ll|l|l|l|l|l|l|l|l|l|l|l|l|l|l|l|l|l|l|l|l|l|l|l}
\hline 経 & 計 279 & 215 & 64 & 1 & 14 & 162 & 58 & 29 & 10 & 5 & 147 & 132 & 67 & 52 & 1 & 26 & 4 & 12 & 59 & 0 & 58 & 46 & 182 & 51
\end{tabular}

第 2 表 昭 和 255 年

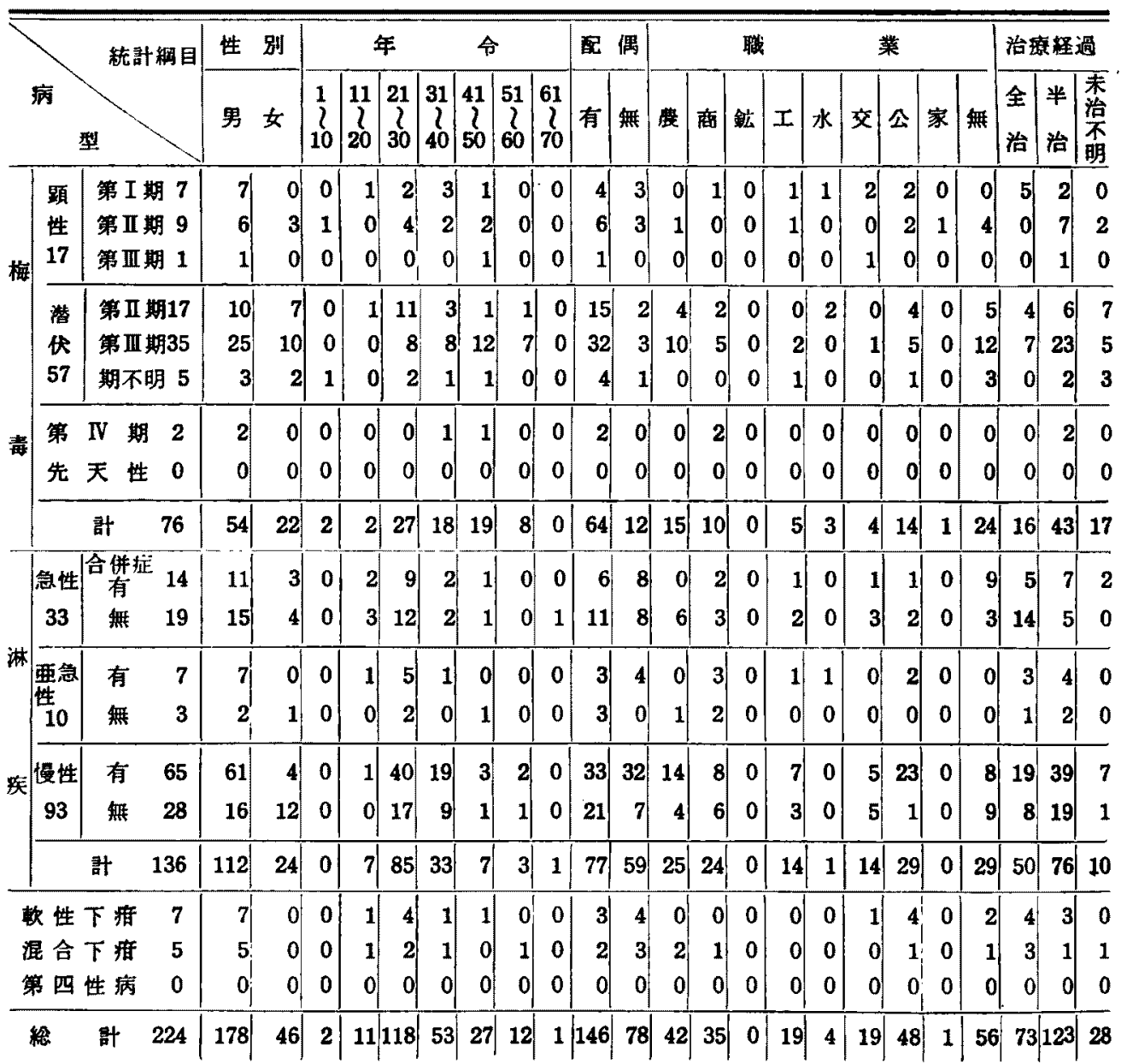


第 3 表 昭 和 26 年

\begin{tabular}{|c|c|c|c|c|c|c|c|c|c|c|c|c|c|c|c|c|c|c|c|c|c|c|}
\hline & 性 別 & & & 年 & & 令 & & & & 偶 & & & 盎 & & & & 業 & & & & 経 & \\
\hline 型 & 男 女 & & 20 & $\begin{array}{c}21 \\
2 \\
30\end{array}$ & $\mid \begin{array}{c}31 \\
2 \\
40\end{array}$ & $\begin{array}{c}41 \\
2 \\
50\end{array}$ & $\left|\begin{array}{c}51 \\
2 \\
60\end{array}\right|$ & $\left|\begin{array}{c}61 \\
2 \\
70\end{array}\right|$ & 有 & 無 & 䟦 & 商醇 & 鉱 & I & 水 & 公 & 公 & 家 & 無 & 石 & & 木 \\
\hline
\end{tabular}

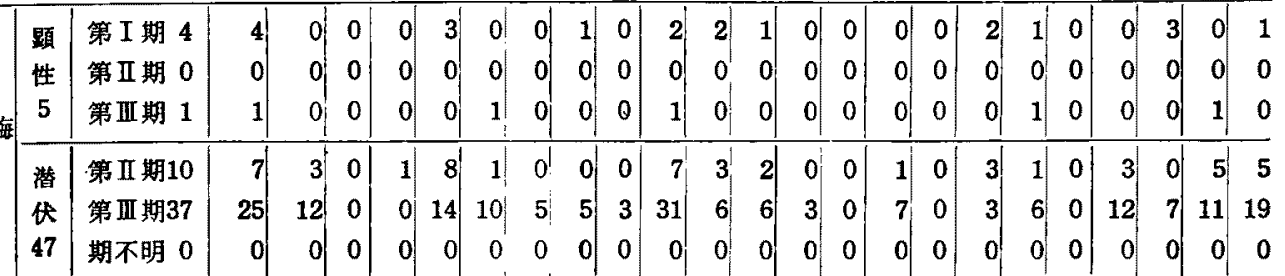

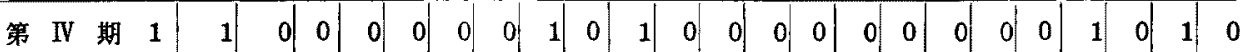
$\begin{array}{lllllllllllllllllllllllll}\text { 先 天 性 } & 3 & 1 & 2 & 3 & 0 & 0 & 0 & 0 & 0 & 0 & 0 & 3 & 0 & 0 & 0 & 0 & 0 & 0 & 0 & 0 & 3 & 0 & 0 & 3\end{array}$

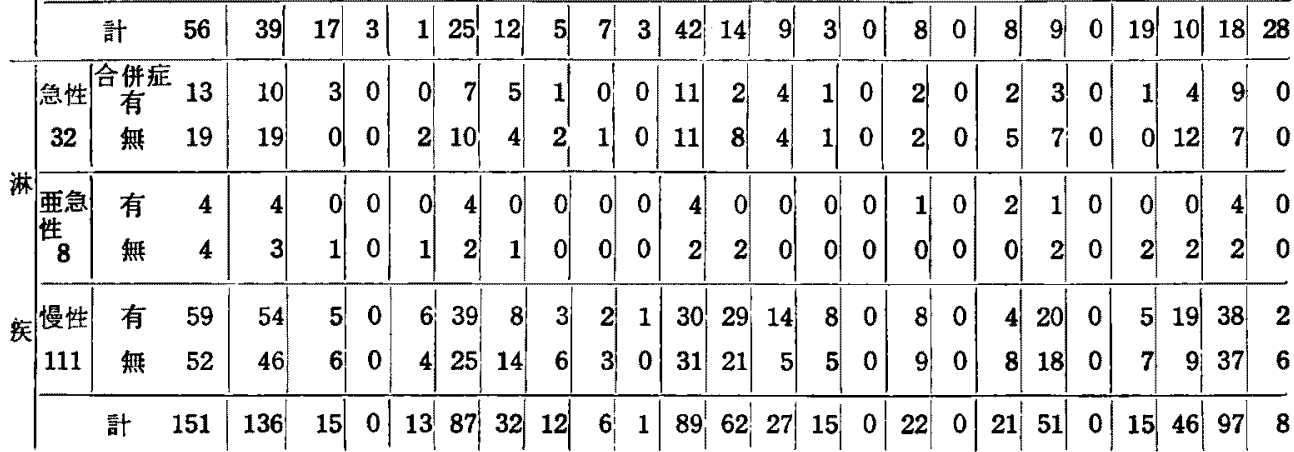

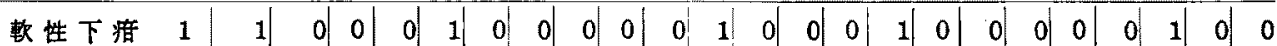
$\begin{array}{lllllllllllllllllllllllll}\text { 搌合下症 } & 2 & 2 & 0 & 0 & 1 & 1 & 0 & 0 & 0 & 0 & 0 & 2 & 0 & 1 & 0 & 0 & 0 & 0 & 0 & 0 & 1 & 1 & 1 & 0\end{array}$

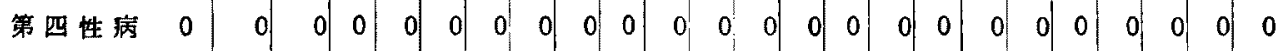

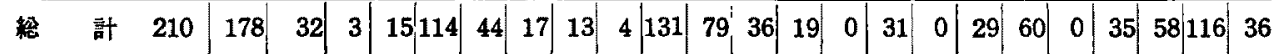

第 4 表 昭 和 27 年

\begin{tabular}{|c|c|c|c|c|c|c|c|c|c|c|c|c|c|c|c|c|c|c|c|c|}
\hline & 性 別 & & & 年 & & 令 & & & 偶 & & & 联 & & & & 業 & & & & 慗経過 \\
\hline 坚 & 男 女 & & $\begin{array}{l}11 \\
2 \\
20\end{array}$ & $\begin{array}{c}21 \\
2 \\
30\end{array}$ & $\begin{array}{c}31 \\
? \\
40\end{array}$ & $\left|\begin{array}{cc}41 & 51 \\
2 & ? \\
50 & 60\end{array}\right|$ & $\begin{array}{c}61 \\
2 \\
70\end{array}$ & 有 & 墲 & 䊁 & 辟 & 鉱 & I & 水 & 文 & 公 & 家 & 無 & & \begin{tabular}{l|l} 
半 \\
治
\end{tabular} \\
\hline
\end{tabular}

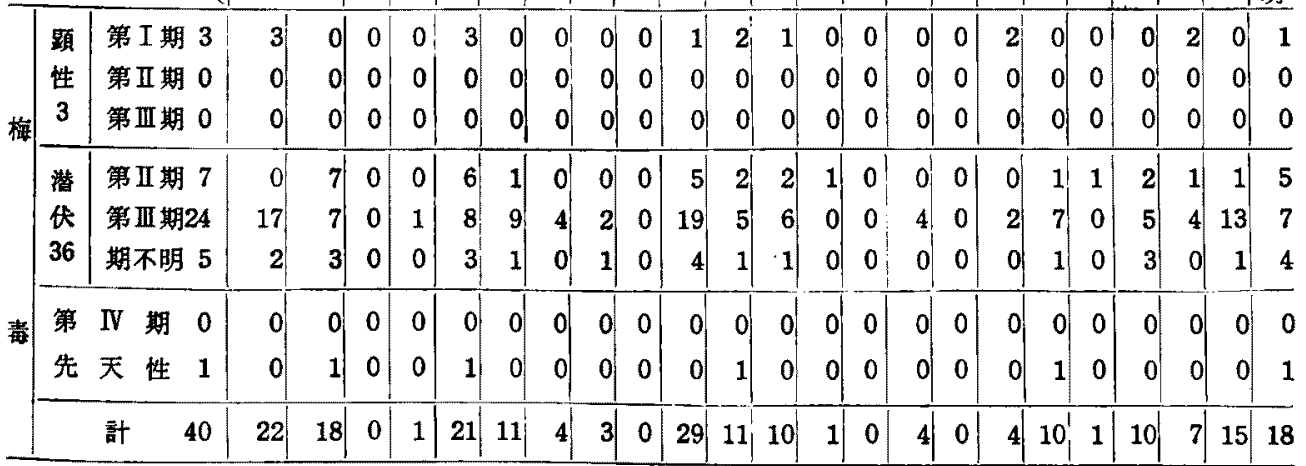




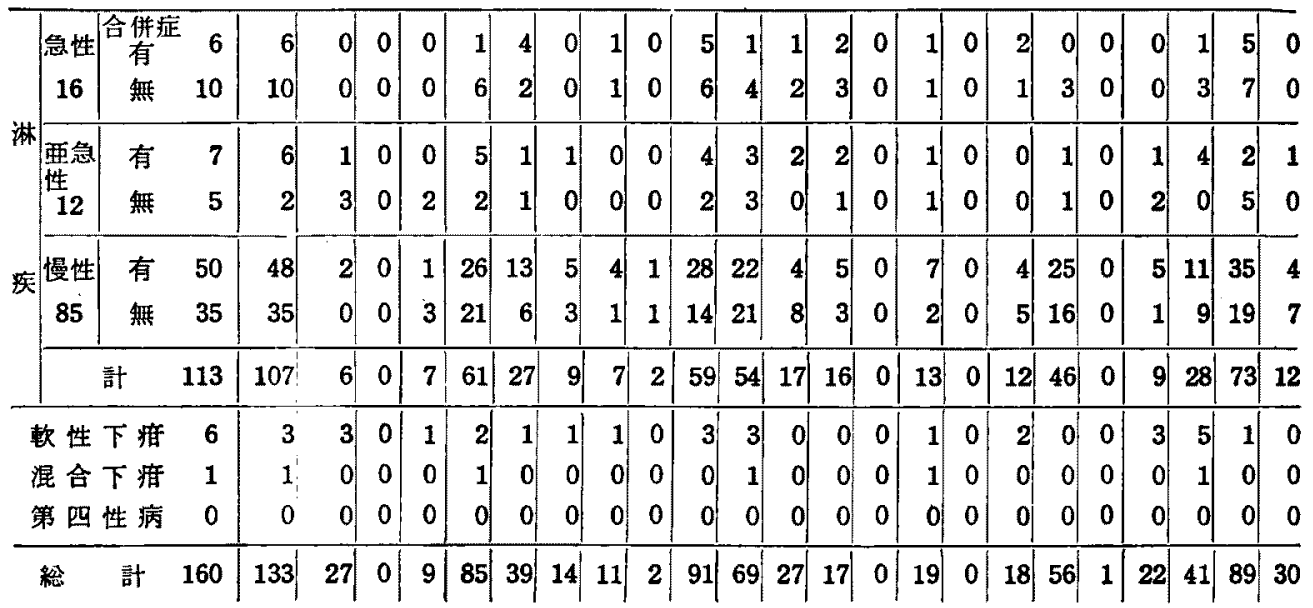

第 5 表 昭 和 28 年

\begin{tabular}{|c|c|c|c|c|c|c|c|c|c|c|c|c|c|c|c|c|c|c|c|c|c|c|c|c|}
\hline & 性 & & \multicolumn{4}{|c|}{ 年 } & \multicolumn{3}{|c|}{ 令 } & \multicolumn{2}{|c|}{ 配 偶 } & \multicolumn{5}{|c|}{ 職 } & \multicolumn{3}{|c|}{ 業 } & & \multicolumn{2}{|c|}{ 治療経過 } \\
\hline & & & & 女 & & $\begin{array}{c}11 \\
2 \\
20\end{array}$ & \begin{tabular}{c|c}
21 & 3 \\
2 & 3 \\
30 & 4
\end{tabular} & & \begin{tabular}{l|l}
1 & 5 \\
0 & 6
\end{tabular} & & & 有 & 無 & 農 & 商 & 銀 & 工 & 水 & 交 & & 家 & 無 & \begin{tabular}{l|l} 
全 & 半 \\
治 & 治
\end{tabular} & $\mid \begin{array}{l}\text { 未 } \\
\text { 治 } \\
\text { 否 }\end{array}$ \\
\hline & 䫓 & 第 I 期 1 & 1 & 0 & 0 & 0 & 1 & 0 & 0 & & 0 & 0 & 1 & 1 & 0 & 0 & & 0 & 0 & 0 & 0 & & & $\begin{array}{ll}0 & 0\end{array}$ \\
\hline & 性 & 第 II 期 0 & 0 & 0 & 0 & 0 & 0 & 0 & 0 & 0 & 0 & 0 & 0 & 0 & 0 & 0 & 0 & 0 & 0 & 0 & 0 & 0 & $\begin{array}{ll}0 & 0\end{array}$ & 00 \\
\hline & 4 & 第正期 3 & 3 & 0 & $0 \mid$ & 0 & 1 & 0 & 1 & 1 & 0 & 3 & 0 & 1 & 0 & 0 & 1 & 0 & 1 & 0 & 0 & 0 & \begin{tabular}{l|l}
0 & 2
\end{tabular} & $\begin{array}{ll}2 & 1\end{array}$ \\
\hline & 潜 & 第II 期 9 & 7 & 2 & 0 & 0 & 3 & 5 & 0 & 1 & 0 & 8 & 1 & 1 & 0 & 0 & 1 & 0 & 1 & 2 & 0 & 4 & \begin{tabular}{l|l}
0 & 5
\end{tabular} & 5 \\
\hline & 伏 & 第 III 期 33 & 25 & 8 & 0 & 0 & 8 & 9 & 7 & 6 & 3 & 30 & 3 & 8 & 4 & 0 & 4 & 0 & 4 & 8 & 0 & 5 & 124 & 48 \\
\hline & 47 & 期不明 5 & 2 & 3 & 0 & 1 & 0 & 2 & 1 & 0 & 1 & 3 & 2 & 1 & 0 & 0 & 1 & 0 & 0 & 2 & 0 & 1 & 0 & 14 \\
\hline & 第 I & IV 期 0 & 0 & 0 & 0 & 0 & 0 & 0 & 0 & 0 & 0 & 0 & 0 & 0 & 0 & 0 & 0 & 0 & 0 & 0 & 0 & 0 & 0 & 00 \\
\hline & & 天性 3 & 3 & 0 & 1 & 1 & 1 & 0 & 0 & 0 & 0 & 0 & 3 & 0 & 0 & 0 & 0 & 0 & 1 & 0 & 0 & 2 & $\begin{array}{ll}0 & 0\end{array}$ & 03 \\
\hline & & 54 & 41 & 13 & 1 & 2 & 14 & 16 & 9 & 8 & 4 & 44 & 10 & 12 & 4 & 0 & 7 & 0 & 7 & 12 & 0 & 12 & \begin{tabular}{l|l}
2 & 32
\end{tabular} & $\begin{array}{l}2 \\
22\end{array}$ \\
\hline & 重性 & $\begin{array}{l}\text { 合併症 } \\
\text { 有 }\end{array}$ & 4. & 2 & 0 & 0 & 2 & 1 & 2 & 1 & 0 & 4 & 2 & 5 & 1 & 0 & 0 & 0 & 0 & 0 & 0 & 0 & $\begin{array}{ll}4 & 2 \\
\end{array}$ & 20 \\
\hline & 21 & 無 15 & 14 & 1 & 0 & 2 & 9 & 1 & 1 & 2 & 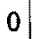 & 5 & 10 & $1 \mid$ & 3 & 0 & 2 & 1 & 0 & 7 & 0 & 1 & \begin{tabular}{l|l}
5 & 10
\end{tabular} & 00 \\
\hline & 亜急 & & 1 & 0 & 0 & 0 & 1 & 0 & 0 & 0 & 0 & 0 & 1 & 0 & 0 & 0 & 0 & .0 & 0. & 1 & 0 & & 01 & 10 \\
\hline & 8 & 無 & 7 & 0 & 0 & 0 & 6 & 1 & 0 & 0 & 0 & 4 & 3 & 0 & 3 & 0 & 0 & 0 & 2 & 2 & 0 & 0 & 16 & 60 \\
\hline & 慢性 & 45 & 43 & 2 & 0 & 1 & 30 & 7 & 5 & 1 & 1 & 25 & 20 & 10 & 2 & 1 & & 0 & & 17 & 0 & 4 & \begin{tabular}{l|l}
5 & 40
\end{tabular} & $10 \quad 0$ \\
\hline & 108 & 63 & 62 & 1 & 0 & 1 & 40 & 15 & 4 & 3 & 0 & 36 & 27 & 13 & 9 & 0 & 6 & 0 & & 25 & 0 & 2 & 652 & \begin{tabular}{ll|l}
52 & 5
\end{tabular} \\
\hline & 言 & 137 & 131 & 6 & 0 & 4 & 88 & 25 & 12 & 7 & 1 & 74 & 63 & 291 & 18 & 1 & 15 & 1 & 14 & 52 & 0 & & $21 \mid 111$ & \begin{tabular}{l|l}
11 & 5
\end{tabular} \\
\hline \multirow{3}{*}{\multicolumn{3}{|c|}{$\begin{array}{l}\text { 軟性下瘄 } \\
\text { 混合下瘄 } \\
\text { 第四性病 }\end{array}$}} & 2 & 0 & 0 & 1 & 1 & 0 & 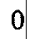 & 0 & 0 & 1 & 1 & $\alpha$ & 0 & 0 & & 0 & 0 & 1 & 0 & 0 & c & \begin{tabular}{l|l}
0 & 1
\end{tabular} \\
\hline & & & 4 & 0 & 0 & 2 & 1 & 0 & 1 & 0 & 0 & 1 & 3 & 3 & 0 & 0 & & 0 & 0 & 1 & 0 & 0 & 1 & $\begin{array}{ll}3 & 0\end{array}$ \\
\hline & & & 0 & 0 & 0 & 0 & 0 & 0 & 0 & 0 & 0 & 0 & 0 & 0 & 0 & 0 & 0 & 0 & 0 & 0 & 0 & 0 & 0 & 0 \\
\hline & & 計 197 & 178 & 21 & 1 & 2 & 104 & $=1$ & 22 & & & 1 & & 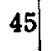 & 22 & 2 & 22 & 1 & 21 & 66 & 0 & $19 \mid$ & $25 \mid 146$ & 1626 \\
\hline
\end{tabular}


第 6 表 炤 和 209 年

\begin{tabular}{|c|c|c|c|c|c|c|c|c|c|c|c|c|c|c|c|c|c|c|c|c|c|}
\hline & 性 別 & & 年 & F & & 令 & & & 配 & & & & 僟 & & & & 業 & & & & 経谓 \\
\hline & 男 女 & $\begin{array}{c}1 \\
2 \\
10\end{array}$ & $\begin{array}{c}11 \\
2 \\
20\end{array}$ & $\begin{array}{c}21 \\
2 \\
30\end{array} \mid$ & $\begin{array}{l}31 \\
2 \\
40\end{array} \mid$ & $\begin{array}{c}41 \\
? \\
50\end{array}$ & \begin{tabular}{c|}
51 \\
$?$ \\
60
\end{tabular} & $\begin{array}{c}61 \\
? \\
70\end{array}$ & 有 & 無 & 脿 & 商 & 鉱 & I & 水 & 交 & 公 & 家 & 無 & & \begin{tabular}{l|l} 
半 \\
治 \\
治采明
\end{tabular} \\
\hline
\end{tabular}

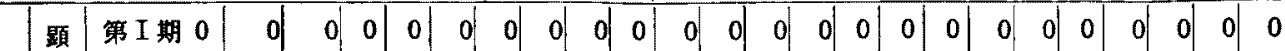

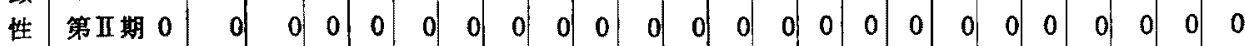

$\begin{array}{lllllllllllllllllllllllllll}1 & \text { 第吕期 } 1 & 1 & 0 & 0 & 0 & 0 & 0 & 0 & 1 & 0 & 1 & 0 & 0 & 0 & 0 & 0 & 0 & 0 & 1 & 0 & 0 & 0 & 1 & 0\end{array}$

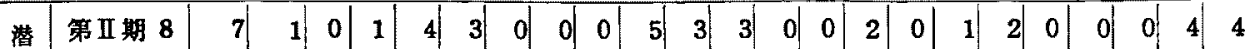

伏

\begin{tabular}{l|l|l|llllllllllllllllllllll}
36 & 期不明 3 & 1 & 2 & 0 & 0 & 1 & 2 & 0 & 0 & 0 & 3 & 0 & 0 & 1 & 0 & 0 & 0 & 1 & 0 & 0 & 1 & 0 & 1 & 2
\end{tabular}

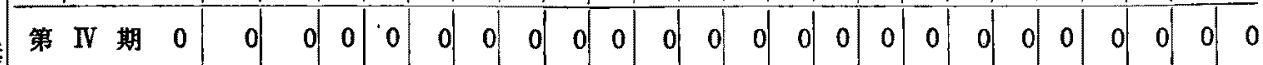

$\begin{array}{llllllllllllllllllllllllll}\text { 先天性 } & 8 & 6 & 2 & 3 & 3 & 2 & 0 & 0 & 0 & 0 & 0 & 8 & 0 & 0 & 0 & 0 & 0 & 1 & 1 & 0 & 6 & 0 & 2 & 6\end{array}$

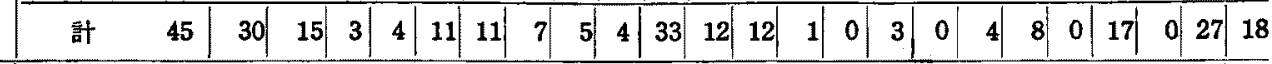

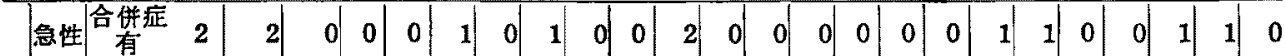

$\begin{array}{llllllllllllllllllllllllll}9 & \text { 無 } & 7 & 7 & 0 & 0 & 1 & 4 & 1 & 1 & 0 & 0 & 2 & 5 & 1 & 0 & 0 & 0 & 0 & 0 & 5 & 0 & 1 & 3 & 4 & 0\end{array}$

淋要急

\begin{tabular}{llllllllllllllllllllllllll}
\hline 4 & 2 & 2 & 2 & 0 & 0 & 0 & 2 & 0 & 0 & 0 & 0 & 1 & 1 & 0 & 0 & 0 & 0 & 0 & 0 & 2 & 0 & 0 & 1 & 1 & 0
\end{tabular}

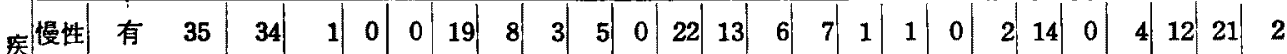

\begin{tabular}{lllllllllllllll|l|l|l|l|l|l|l|l|l|l}
74 & 39 & 36 & 3 & 0 & 1 & 22 & 7 & 5 & 3 & 1 & 25 & 14 & 5 & 5 & 1 & 2 & 0 & 7 & 14 & 0 & 5 & 8 & 28 & 3
\end{tabular}

\begin{tabular}{ll|l|l|l|l|l|l|l|l|l|l|l|l|l|l|l|l|l|l|l|l|l|l|l} 
計 & 87 & 83 & 4 & 0 & 2 & 49 & 16 & 11 & 8 & 1 & 54 & 33 & 13 & 12 & 2 & 4 & 0 & 10 & 36 & 0 & 10 & 26 & 56 & 5 \\
\hline
\end{tabular}

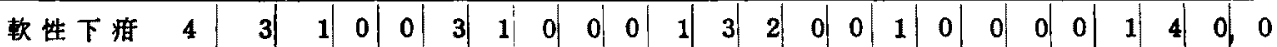

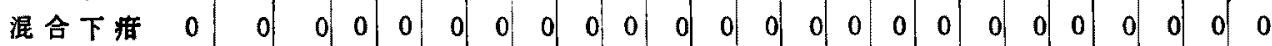

$\begin{array}{llllllllllllllllllllllllll}\text { 第四性病 } & 0 & 0 & 0 & 0 & 0 & 0 & 0 & 0 & 0 & 0 & 0 & 0 & 0 & 0 & 0 & 0 & 0 & 0 & 0 & 0 & 0 & 0 & 0 & 0\end{array}$

\begin{tabular}{lll|l|l|l|l|l|l|l|l|l|l|l|l|l|l|l|l|l|l|l|l|l|l} 
䌊 & 計 136 & 116 & 20 & 3 & 6 & 63 & 28 & 18 & 13 & 5 & 88 & 48 & 27 & 13 & 2 & 8 & 0 & 14 & 44 & 0 & 28 & 30 & 83 & 23
\end{tabular}

第 7 表 昭 和 30 年

\begin{tabular}{|c|c|c|c|c|c|c|c|c|c|c|c|c|c|c|c|c|c|c|c|c|c|c|c|c|c|}
\hline \multirow{2}{*}{\multicolumn{3}{|c|}{ 病 統計網目 }} & 性 & & \multicolumn{4}{|c|}{ 年 } & \multicolumn{3}{|c|}{ 令 } & \multicolumn{2}{|c|}{$\mid \begin{array}{ll}\text { 配 } & \text { 偶 }\end{array}$} & \multicolumn{6}{|c|}{ 㨫 } & \multicolumn{3}{|c|}{ 業 } & \multicolumn{3}{|c|}{ 治療経過 } \\
\hline & & & 男 & & $\begin{array}{l}1 \\
3 \\
10\end{array}$ & & $\begin{array}{c}21 \\
? \\
30\end{array}$ & \begin{tabular}{c|c}
31 & 4 \\
40 & 5
\end{tabular} & & & $\begin{array}{l}61 \\
2 \\
70\end{array}$ & 有 & 䇫 & 慒 & 䁤 & 鉱 & $I$ & 水 & 交 & 公 & 家 & 慜 & $\begin{array}{l}\text { 全 } \\
\text { 治 }\end{array}$ & & 查 \\
\hline & 顥 & 第 $I$ 期 0 & 0 & 0 & 0 & 0 & 0 & 0 & 0 & 0 & 0 & 0 & 0 & 0 & 0 & 0 & & 0 & 0 & & 0 & 0 & 0 & & 0 \\
\hline & 性 & 第 II 期 0 & 0 & 0 & 0 & 0 & 0 & 0 & 0 & 0 & 0 & 0 & 0 & 0 & 0 & 0 & 0 & 0 & 0 & 0 & 0 & 0 & 0 & 0 & 0 \\
\hline & 0 & 第而期 0 & 0 & 0 & 0 & 0 & 0 & 0 & 0 & 0 & 0 & 0 & 0 & 0 & 0 & 0 & & 0 & 0 & 0 & 0 & 0 & 0 & 0 & 0 \\
\hline & 潜 & 第 II期 3 & 1 & 2 & 1 & 2 & 0 & 0 & 0 & 0 & 0 & 2 & 1 & 0 & & 0 & & 0 & 1 & 1 & 0 & 1 & 0 & 2 & 1 \\
\hline & 伏 & 第 III期13 & 7 & 6 & 0 & 0 & 5 & 2 & 5 & 0 & 1 & 10 & 3 & 1 & 4 & 0 & & 0 & 2 & 1 & 0 & 5 & 0 & 5 & 8 \\
\hline & 16 & 期不明 0 & 0 & 0 & 0 & 0 & 0 & 0 & 0 & 0 & 0 & 0 & 0 & 0 & & 0 & 0 & 0 & 0 & & 0 & 0 & 0 & 0 & 0 \\
\hline & & IV 期 0 & 0 & 0 & 0 & 0 & 0 & 0 & 0 & 0 & 0 & 0 & 0 & 0 & & 0 & 0 & 0 & 0 & & 0 & 0 & 0 & 0 & 0 \\
\hline & & 天性 & 2 & 1 & 1 & 1 & 1 & 0 & 0 & 0 & 0 & 0 & 3 & 0 & 0 & 0 & & 0 & 0 & & 0 & 2 & 0 & 0 & 3 \\
\hline & & 19 & 10 & 9 & 2 & 3 & 6 & 2 & 5 & 0 & 1 & 12 & 7 & 1 & & 0 & 0 & 0 & 3 & & 0 & 8 & 0 & & 12 \\
\hline
\end{tabular}




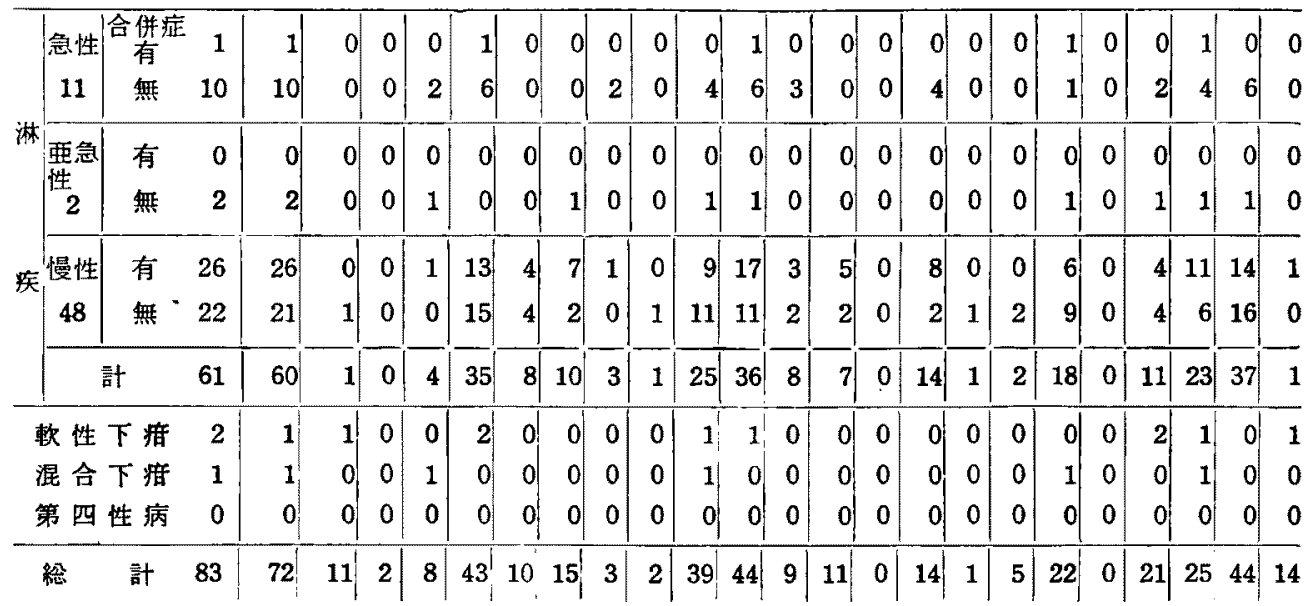

第 8 表 昭 和 $3 \quad 1 \quad$ 年

\begin{tabular}{|c|c|c|c|c|c|c|c|c|c|c|c|c|c|c|c|c|c|c|c|c|c|c|}
\hline & & & & 年 & & & 令 & & & 偶 & & & 耳 & & & & 業 & & & & 尞経j & 佳過 \\
\hline 型 & 男 & & \begin{tabular}{c|c}
1 & 1 \\
10 & 2
\end{tabular} & \begin{tabular}{c|c}
11 & 2 \\
2 & 3 \\
20 & 3
\end{tabular} & \begin{tabular}{c|c}
21 & 31 \\
3 & $\underbrace{30}$ \\
40
\end{tabular} & \begin{tabular}{l|l}
1 & 41 \\
0 & $?$ \\
0 & 50
\end{tabular} & $\left|\begin{array}{c}51 \\
? \\
60\end{array}\right|$ & $\mid \begin{array}{c}61 \\
? \\
70\end{array}$ & 有 & 然 & 㻃 & 商 & 鎕 & I & 水 & 交 & 公 & 家 & 無 & 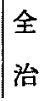 & $\begin{array}{l}\text { 半 } \\
\text { 治 }\end{array}$ & \\
\hline
\end{tabular}

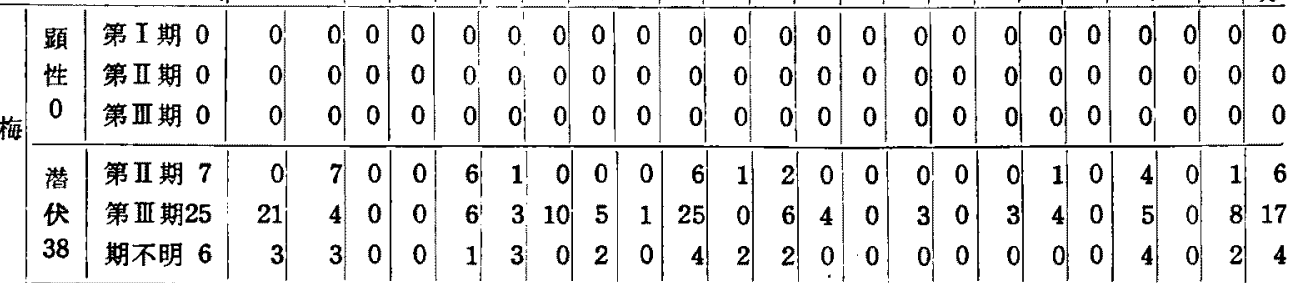

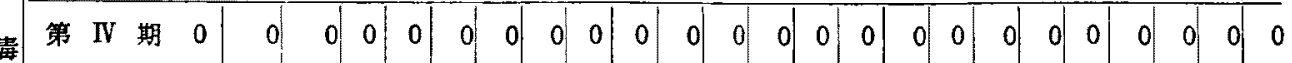
\begin{tabular}{ll|lllllllllllllllllllllll} 
先 天 性 4 & 4 & 3 & 2 & 0 & 2 & 0 & 0 & 0 & 0 & 2 & 2 & 0 & 0 & 0 & 0 & 0 & 0 & 2 & 0 & 2 & 0 & 0 & 4
\end{tabular}

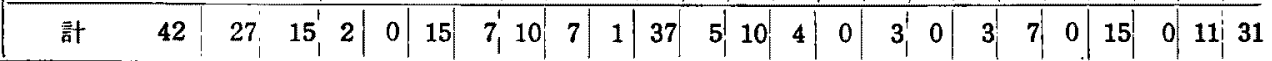

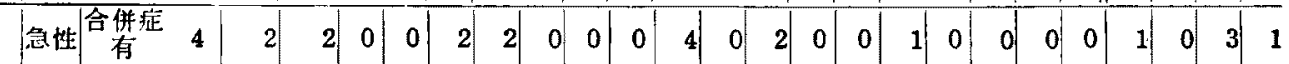
\begin{tabular}{|l|ll|llllllllllllllllllllllll}
14 & 舠 & 10 & 10 & 0 & 0 & 2 & 8 & 0 & 0 & 0 & 0 & 0 & 10 & 2 & 0 & 0 & 1 & 0 & 1 & 5 & 0 & 1 & 5 & 5 & 0 \\
\hline
\end{tabular}

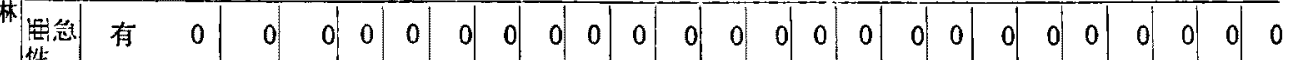
\begin{tabular}{llllllllllllllllllllllllll}
\hline & 3 & 3 & 3 & 0 & 0 & 0 & 2 & 1 & 0 & 0 & 0 & 1 & 2 & 1 & 0 & 0 & 1 & 0 & 0 & 1 & 0 & 0 & 0 & 1 & 2
\end{tabular}

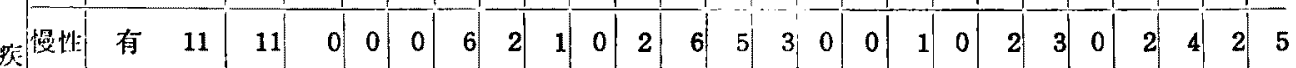

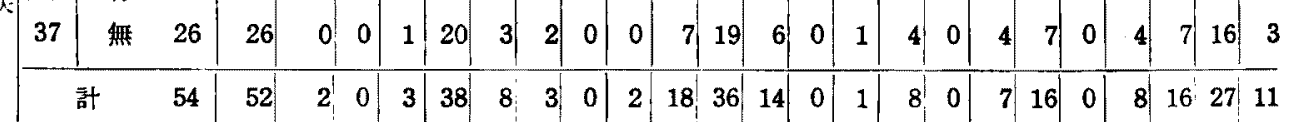

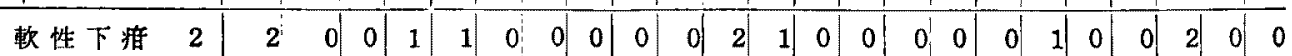

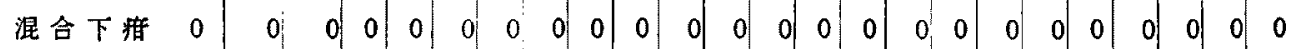

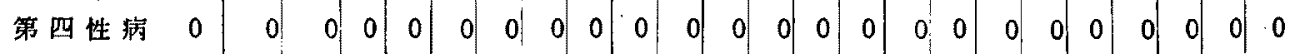
\begin{tabular}{ll|l|ll|l|l|l|l|l|l|l|l|l|l|l|l|l|l|l|l|l|l|l|l} 
総 部 98 & 81 & 17 & 2 & 4 & 54 & 15 & 13 & 7 & 3 & 55 & 43 & 25 & 4 & 1 & 11 & 0 & 10 & 24 & 0 & 23 & 18 & 38 & 42
\end{tabular} 


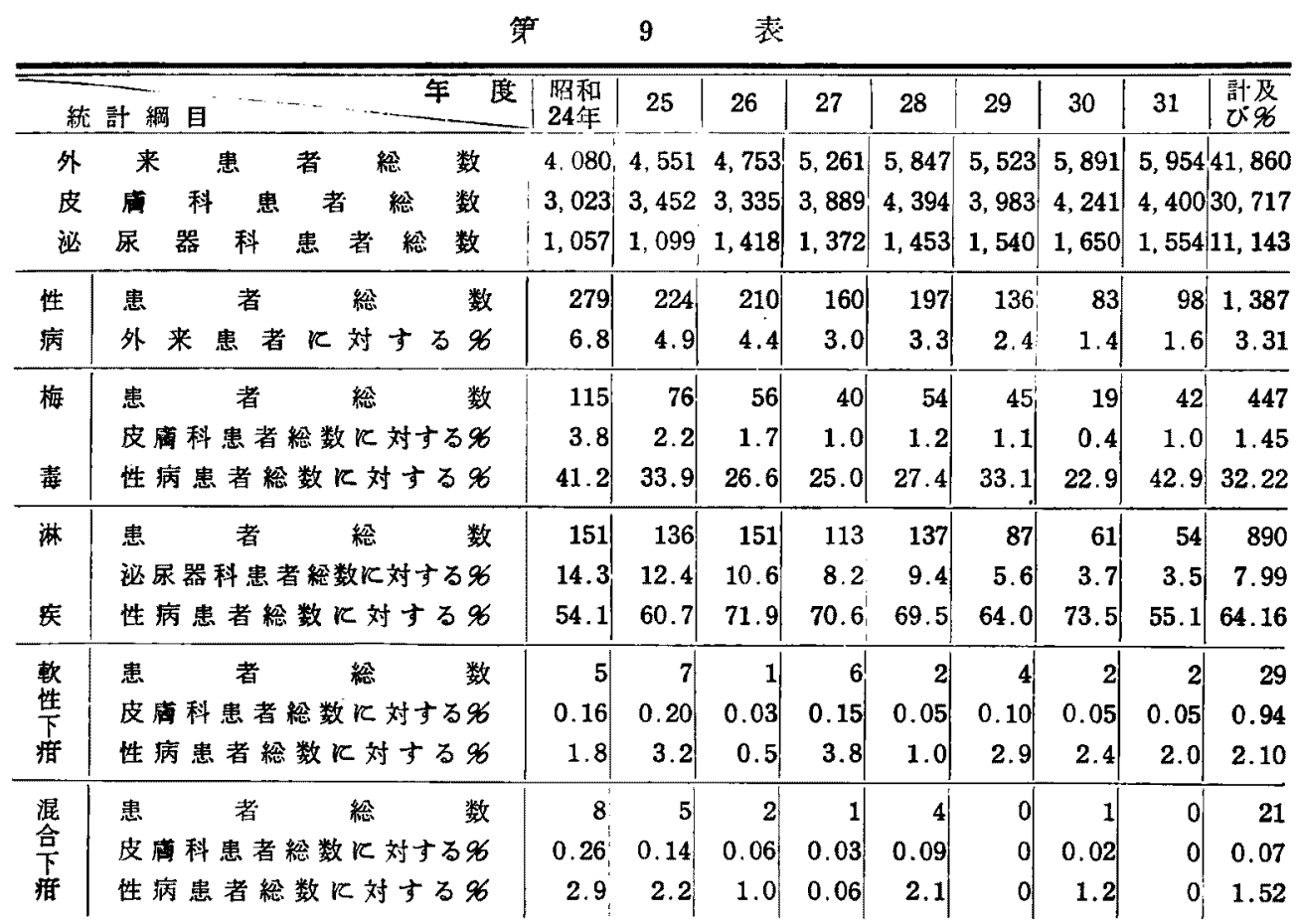

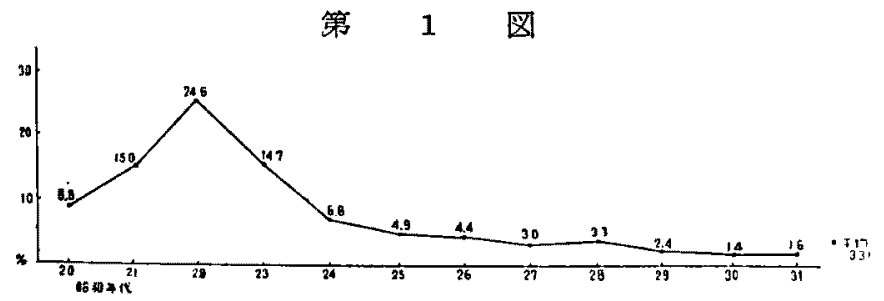

22年13.94\%, 23年13.43

96, 24 年 12.5 \%, 25 年 $10.4 \%, 26$ 年 $6.00 \%$,

27年4.73\%，28年 $4.7 \%$, 29 年 $4.5 \%$ と報告し，北 大湉いては昭和 20 年 $5.9 \%, 21$ 年 $9.6 \%, 22$

昭和120年終戦後のものを参照し，之等の表 そあらわれた数字を図示してみると次のよう になる、第1四に扣いては性病患者総数の外 来患者総数火対する名を亦す，彇和22年最高 24.69より年々下降し，畦和30年に $1.4 \% 0$ 最低となり，8ケ年の平汮は3.31\%て，昭和

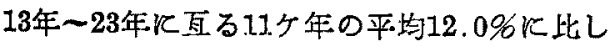
激減している。性病患者の外来を訪稀る \%の減少は，ベニンリン或はその他優秀 なる抗生物質の普及にあることは異陯が ないが，一般に性病患者が減少したとは 断言てきない.

最近の 2,3 大学並びに病院の外来患 者総数に対する\%を眺めるに，千菜大に 衫いては昭和 20 年 8.7\%, 21 年 $10.8 \%$,

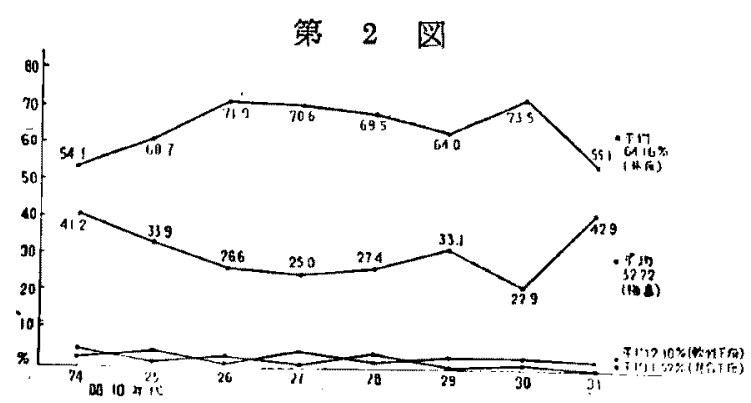


2）第 2 図に打いては各種性病の业病患者 秎数飞対する名を示す. 即ち平均淋奖は64.16 \%，梅海は $32.22 \%$ ，欶性下活は $2.10 \%$ ，混 合下括は1.52\% となつて打り，第四性病は 8 ケ年を通じ 1 例子みない（第 2 図参考）。

3）第 3 区に括いては梅毒中第IV期，先天 性考除き，顥症梅毒（第 I，II，III期）の\% を示す，終戦後21年に最高 $34.5 \%$ を示し，以 来階段状飞减少をみ，30年，31年飞は顕症梅 毒は1例すみられなかつた（第 3 図参考）。

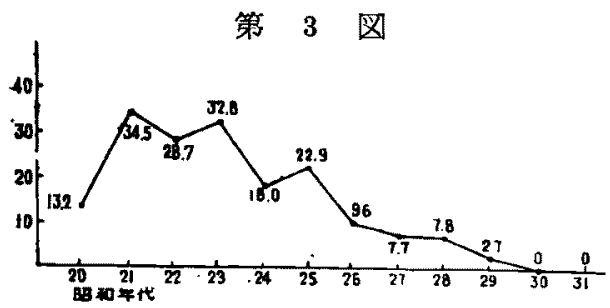

4）第 4 図に打いて㾁淋疾中急性なるるの 196 を示す．終戦以来24年《14.5\%と一つの 谷を作り，29年最低12.696より上开の気味が みられる(第 4 図参考)。

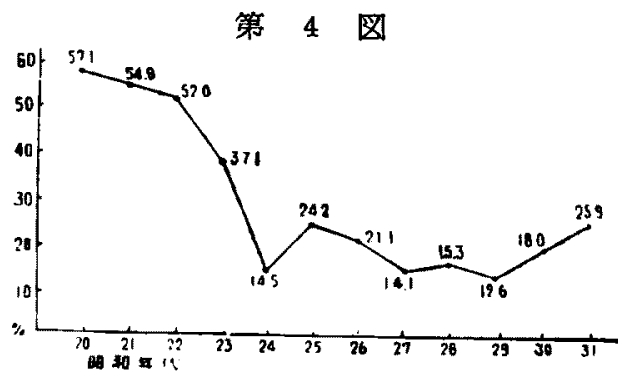

5）第5因に和いては性別，男子患者の\% を示す. 21年に90.7\%，28年に90.396 と戦後 二つの山がみられ，こ」 2,3 年来低下の感 がある，男子患者の減少は，䀦人患者の增加 したことを示するので，性病の家庭侵入を物 語るるのといえる(第 5 因参荅).

第 5 因

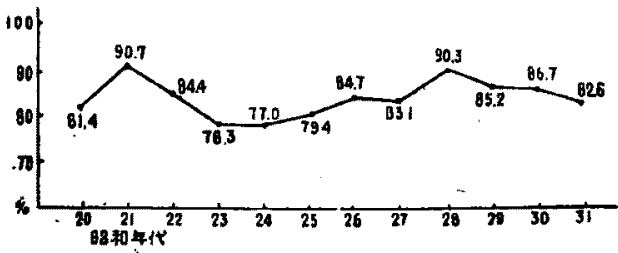

6）第 6 四炕括いては20才代患者の\%を梅 毒，淋疢飞分類して図示したるので，淋疾は

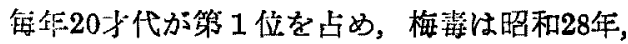
29年以外はやはり20才代が第 1 位を占めてい る.このことは青年子女の性病についての知 識の乏しいこと〉，心の荒廃を示すといえる (第 6 図参考).

第 6 因

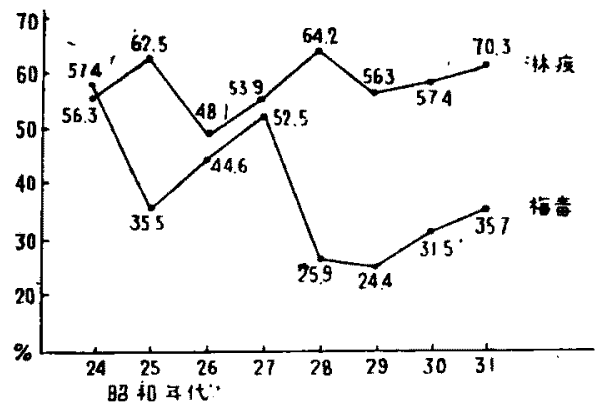

7）配偶関係においては 8 ケ年を通し，既 婚 817 ，末婚 570 ，既婚者の96 58.9\%。，但 乙昭和30年，31年にては淋疾患者中未婚者の 方が既婚者よりる多数を占めた。

8）職業関係においては，第10表に示す通 りで，交は鉄道員，運転手，船員を，公は公 務自由業，事務員を，家は家事使用人を示し たもので，8ケ年を通じ公，農，無，商，工， 䒘，水，鉱，家の順となつている，職業に扔 いては当時の洔代相を示し，経済状態が大い と関係すると思われ，藤原氏等の統計飞よれ ば，日華事变中は商，無，農の順，大平洋戦 争中は公，無，工の順，'終戦後は無，農，公 の順であると（第 10 表参考).

9）治療経過は第11表飞示す，全治，半治。 末治及び不明と分け，半治とは軽快し治療中 途にて通院を止めたるの，未治及び不明とは 通院中であるが末だ治虑に至らないるの，或 は診祭のみにて治療は全タ行つていないるの をい5，梅毒に括いては，全治とは所定のク 一ルを完全に行い，梅毒血清反岕即ちワ氏， 村田氏，カーン氏反応陰性化し，或は抗体価 の緒方法20倍以下，緒方凝集法 8 倍以下とな りしもの，未治及び不明とは治療経続中のる の及び血液検查のみを行い，以後の治療を当 
第 100 表

\begin{tabular}{|c|c|c|c|c|c|c|c|c|c|}
\hline 年 別 & 農 & 商 & 泫 & $I$ & 水 & 交 & 公 & 家 & 無 \\
\hline 24 & 67 & 52 & 1 & 26 & 4 & 12 & 59 & 0 & 58 \\
\hline 25 & 42 & 35 & 0 & 19 & 4 & 19 & 48 & 1 & 56 \\
\hline 26 & 36 & 19 & 0 & 31 & 0 & 29 & 60 & 0 & 35 \\
\hline 27 & 27 & 17 & 0 & 19 & 0 & 18 & 56 & 1 & 22 \\
\hline 28 & 45 & 22 & 1 & 22 & 1 & 21 & 66 & 0 & 19 \\
\hline 29 & 27 & 13 & 2 & 8 & 0 & 14 & 44 & 0 & 28 \\
\hline 30 & 9 & 11 & 0 & 14 & 1 & 5 & 22 & 0 & 21 \\
\hline 31 & 25 & 4 & 1 & 11 & 0 & 10 & 24 & 0 & 23 \\
\hline 計 & 278 & 173 & 5 & 150 & 10 & 128 & 379 & 2 & 262 \\
\hline 96 & 20.04 & 12.47 & 0.36 & 10.82 & 0.72 & 9.22 & 27.33 & 0.15 & 18.89 \\
\hline
\end{tabular}

大学にて行ってないものをいう．淋疾に招い ては，全治とは尿全く清澄となり，検鏡した ところ淋菌，白血球の全く消失したものであ ๖.

8 ケ年の平均成績と昭和31年の経過とを比 較してみるに，31年には淋疾の全治せる\%は 增加しているが，梅毒においては末治及び不 明の多が增加している. 当教室昭和23年度に 全治せるるの今\%は，梅毒20.0\%，淋疾25.1 \%, 軟性下唐 $50.0 \%$, 混合下㳻 $20.4 \% \mathrm{~K} \tau$, 梅毒以外の性病は明か飞治療成績が次第に上 昇していることを示し，梅毒に扔いては抗療 梅毒が残存していることを物語るすのといえ る(第 11 表参考).

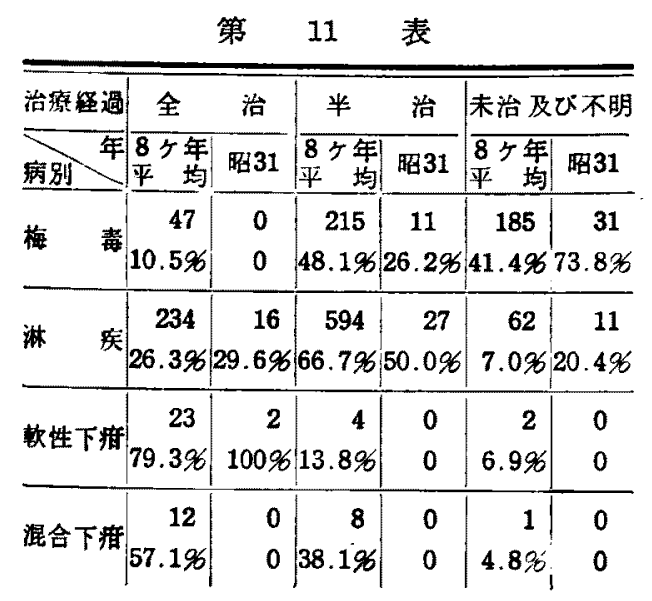

総括

1）戦後著しく兴延した性病も，昭和22年
を最高として年ヶ下降し，当教室における性 病患者総数の外来患者総数仅対する96は，昭 和 24年～31 年住る8 ケ年間平均 3.31\%で あるが，実際性病患者が隇少したとは考えら れない.

2）各種性病間の割合は 8 ケ年を通じ，淋 疾 64.16\%，梅毒 32.22\%，軟性下活 $2.10 \%$, 混合下瘏 $1.52 \%$ 亿て第四性病は 1 例子みられ ない.

3）感染の危険の大きい顕症梅毒は次第に その数を減し，昭和 30 年, 31年には1例もみ られなかつた。急性淋疾の淋疾患者総数に対 する\%は昭和 24 年 14.596 よ，以後著しい 増減はなく昭和29年12.69 と最低を示してい るが, 急性淋疾患者が終戦直後飞此較し減少 したとは断言できない。

4）性別とついては，昭和 24 年男子患者 $77.0 \%$ 上り昭和 28 年 $90.3 \%$ 上昇し, 昭和 31 年 82.6 名と再び下降を示している，男子 思者の減少は媂人患者の增加を物語るすので, 性病の家庭侵入を示すといえる。

5）年令については，8ケ年を通じ20才代 が第1位を占め，昭和28年梅毒患者に括いて のみ30才代が例外的に多数となつて抢る。

6）配偶関係水括いては，8ケ年を通し既 婚者58.9\%にて未婚者を凌唯している。

7）联業に括いては当洔の経清状態が火い 阙係すると思われ，公狢自由業が最高 27.33 安示した。 
8）治療成績については, ペニンリン或は 年タみているが, 梅毒に和いては, 抗療梅毒 その他優秀なる抗生物質により，その向上を の残存がみられる。

文献
1) 藤原外：性病, 35, 130, 昭25.
3）大越外：性病，40，76，昭30.
2) 吉峰: 性病, 40,1 , 昭 30 .
4) 平林外：性病, 41，49, 昭31.

\section{Epidemiologic Studies on Venereal Diseases in Okayama District. Report III. \\ Statistical Observations on Venereal Diseases during past eight years (from 1949 to 1956) in the clinic of the Department of Dermatology and Urology, Okayama University Hospital. \\ Eitaro Yamamura \\ Kunisuke Isei}

Department of Dermatology and Urology, Okayama University Medical School, Okayama.

(Director: Prof. J. Omura)

This paper is presented the vicissitude of the venereal diseases, syphilis, gonorrhea, ulcus molle, ulcus mixtum and lymphogrannlomatosis venereum in past eight years from 1949 to 1956.

In general, syphilis and gonorrhea have been decreased after the war, especially syphilis is marked and no patients visited in 1955 and 1956.

This shows the influence of the effective use of the antibiotics, but seems to be obscured the latent type. 